ROCZNIKI TEOLOGICZNE

Volume LXV, issue $10-2018$

Englis h version

DOI: http://dx.doi.org/10.18290/rt.2018.65.10-3en

URSZULA DUDZIAK

\title{
THE BIBLICAL CALL FOR PARENTS TO RAISE THEIR CHILDREN
}

\begin{abstract}
One of the main assignments for spouses is to transmit life. It is not enough to do this only in a physical way, but also in the mental, spiritual and social dimensions. Transmitting life is not simply procreation, but also education. Christian parents should learn about bringing up children from the texts of the Holy Bible. This will help them to fulfill their duties at the beginning of the journey of their married life. The parenting commitment is beneficial for their offspring, country, the Church and world.
\end{abstract}

Keywords: Holy Bible; parents; children; upbringing; educate; raise.

People were created in the image and likeness of God, and they received a specific task from their creator related with transmitting life, to populate the earth and tend to it by their work (Gen 1, 27-31; Gen 2, 4-7.15). Yet, Adam and Eve's first sons, even though they carefully did their work by tending for the flocks and harvesting the fields, failed in their interpersonal relationships due to their improperly formed personality traits. Cain's temperament led to murdering his brother Able. The effects of our first parents' sin revealed negative tendencies in the next generation. These tendencies required rooting out by concrete educational efforts leading to mastering one's negative personality traits and replacing them with positive traits.

Physical health without spiritual health is not enough, meaning proper upbringing. Cain does not know how to cope with his negative emotions: "Then the LORD said to Cain: Why are you angry? Why are you downcast? If you act rightly, you will be content; but if not, sin lies in wait at the door: its urge is for you, yet you can rule over it" (Gen 4:6-7). Disobedience and lack of forgiveness, rivalry, jealousy, envy, and anger led him to plan revenge: he said "let's go into the fields" (Gen 4:8) and there he killed his

Dr. Hab. Urszula DudziaK, KUL Professor at the Chair of Family Psychology and Pedagogy, Institute of Family Studies and Social Work, John Paul II Catholic University of Lublin; correspondence address: Al. Racławickie 14, 20-950, Lublin; e-mail: ududz@kul.pl 
brother. Emotional instability and unrighteousness in the area of morality went even further in the wrong direction in Cain's generation: "Sevenfold vengeance for Cain, but seventy-sevenfold for Lamech" (Gen 4:24). The Canites, as opposed to the Sethites, Seth's children who took the place of slain Able, have no ties to God, since they do not pray and are not obedient to him. The life principles that lead them are reflected in their savage nature and vindicativeness (Gen 4:26b). That's the way people behave whose will is not subjected to spiritual direction, and their behavior does not reflect God the Father's love.

The behavior of individuals, interaction among groups and the functioning of society in general require proper orientation. Forming attitudes is achieved through upbringing. ${ }^{1}$ Thanks to this, it is also possible to learn, promote and implement the correct principles governing social life. Respect, culture and proper behavior enable people to build positive bonds and achieve common goals. These are indispensable for the functioning of societies, but also for personal growth in goodness and self-improvement. This path brings us closer to sanctity and makes love a reality by allowing us to prepare a place for ourselves in eternity.

The problem of the lack of upbringing and submitting one's own behavior to spiritual direction ${ }^{2}$ is also evident in modern times. Earning money, doing a career, seeking pleasures, and social media take up parents' time, yet they should devote their lives to their children. It is easy for parents to assign their obligations to raise their children to others or delude themselves with the illusory hope that bringing up their children will take place by itself and not require the involvement of parents. Children sent to nurseries and preschools, wandering out in the streets, surrounded by youth subcultures, the Internet and computer games, register the negative examples of their always absent parents, and have no meaningful conversations with them. Thus, children have no way to cope with contemporary reality, and so they do not

\footnotetext{
${ }^{1}$ Maria PrZetacznik-Gierowska, Ziemowit WŁodArski, Psychologia wychowawcza (Warszawa: Wydawnictwo Naukowe PWN, 2017); Czesław WALESA, "Psychologiczna analiza rozwoju religijności człowieka ze szczególnym uwzględnieniem pierwszych okresów jego ontogenezy," in Psychologia religii, edited by Zdzisław Chlewiński (Lublin: TN KUL, 1982), 143-180; Tomasz BORKOWSKI, "Wartości religijne. Kształtowanie postaw religijnych człowieka," Fides et Ratio 1(17) (2014): 166-178; Piotr MAZur, Podstawy pedagogiki pastoralnej (Kraków: Wyższa Szkoła Filozoficzno-Pedagogiczna "Ignatianum," Wydawnictwo Apostolstwa Modlitwy, 2011), 328-350; Marek DZIEWIECKI, Wychowanie duchowe, moralne i religijne chtopców. Od urwisa do bohatera (Kraków: Wydawnictwo eSPe, 2013).

${ }^{2}$ Sztuka kierownictwa duchowego, ed. Józef Augustyn, Jakub Kołacz (Kraków: Wydawnictwo Apostolstwa Modlitwy, 2007).
} 
know how to accept moral norms, chose what is good and undertake personal responsibilities.

God, entrusting Jesus to the family of Nazareth, not only pointed to the value of the family and the great gift it is for people, but also instructed parents about their obligations towards children, who are a gift given to children, who are also their assignment. Fathers and mothers should always keep in mind their commitment to raise their children, to give them good teachings, in season and out of season, correct their mistakes, instruct and patiently raise their spirits (see $2 \mathrm{Tm} 2: 2$ ). Parents must be supported in the formation of the younger generation. These are not easy tasks, especially in the face of many internal and external threats that can distort the development of a child.

The goal of this article, apart from presenting the need and value to raise children, is to point out the older generation's commitment towards the younger, especially parents towards children (NRP, No. 5). The author's goal is to present the educational indications contained in the Old and New Testaments and the incentives to implement them. Educating is in fact included in the vocation of parenthood. Parents are predestined to do so, being talented and equipped with the necessary parental authority. They should know about this responsibility and treat the subject of raising their children as requiring a special commitment. Parents should acquire knowledge and skills, learn proven methods and age-old recommendations.

It is important that parents appreciate their role, understand the greatness and importance of the task entrusted to them, and spend time doing it. Parental efforts can and should be effective, bringing good results in the lives of children. The role of parents is to raise children to be the citizens of heaven, preparing them for communion with God. The parental task of raising children according to the faith, protecting them from contamination with sin and caring for their continuous spiritual development are necessary so that "they always act as children of the light,", as the priest reminds parents during the liturgy of baptism. He also requires the Godparents to keep their obligation to help the parents of the baptized children in fulfilling their duties to properly raise a child. This is another confirmation of the greatness of the undertaken work.

\footnotetext{
${ }^{3}$ Obrzędy Chrztu dzieci dostosowane do zwyczajów diecezji polskich (Katowice: Księgarnia Św. Jacka, 2005), 49.
} 
New educational theories and proposals are constantly appearing in pedagogy. ${ }^{4}$ It is worth knowing that there is also Biblical pedagogy, ${ }^{5}$ which Catholic parents should be particularly interested in. This is all the more important, since in addition to specific indications, God, by assigning parenting tasks, supports them by the grace needed to perform parental duties. An important argument for authentic involvement in the education of offspring also seems to be the fact that a woman and a man, when accepting the sacrament of marriage, must give a positive answer to the question: "do you want to accept and raise the children that God gives you?"

A reminder of the Biblical contents on parents raising children should help and motivate them to fulfill this commitment. These texts are worth recalling, and they even serve family life counselors providing professional support to people preparing for the sacrament of marriage as well as spouses and parents.

\section{EDUCATIONAL INSTRUCTIONS IN THE OLD TESTAMENT}

In the Old Testament, sacred scriptures explicitly recommend that parents convey educational contents to children. The concepts of "upbringing," "educating," "bringing up" and "educator" are repeated many times in the Old and New Testaments. They also present an educational concept and the goals that are important for a pupil in everyday life, which opens them up to eternity: faith in God and following his commandments, love of God and man, and keeping one's undefiled dignity as a child of God for eternal life. God the Father's instructions given to people are an expression of his love for mankind. A happy man is someone "who fears the Lord and walks in his

\footnotetext{
${ }^{4}$ Stefan Kunowski, Podstawy wspótczesnej pedagogiki (Warszawa: Wydawnictwo Salezjańskie, 2004); Bogusław ŚLIWERSKI, Wspótczesne teorie i nurty wychowania (Kraków: Impuls, 2001); Krystyna ChaŁAs, Wychowanie ku wartościom. Elementy teorii i praktyki (Lublin-Kielce: Jedność, 2006); Marian NowAK, Teorie i koncepcje wychowania (Warszawa: Wydawnictwo Akademickie i Profesjonalne, 2008); Religijno-moralny wymiar rozwoju i wychowania, ed. Alina Rynio, Katarzyna Braun, Anna Lendzion i Danuta Opozda (Lublin: Wydawnictwo KUL, 2012).

${ }^{5}$ Jerzy Bagrowicz, Stanisław Jankowski, „Pan Bóg twój, wychowuje ciebie” (Pwt 8,5). Studia $z$ pedagogii biblijnej (Toruń: Wydawnictwo UMK, 2005); Roman B. SIEROŃ, wychowania chrześcijańskiego wedtug św. Pawta Apostoła, wyd. 2 uzup. (Ružomberok-Stalowa Wola: Wydawnictwo Diecezjalne i Drukarnia w Sandomierzu, Katedra Pedagogiki Katolickiej KUL, 2008).

${ }^{6}$ Obrzędy Sakramentu Matżeństwa dostosowane do zwyczajów diecezji polskich (Katowice: Księgarnia Św. Jacka, 2007), 29.
} 
ways," and in addition to life-oriented signposts, God also assures him that "he will be blessed and prosper" (Ps 128:1-2b).

The instructions which the entire book of Deuteronomy is devoted to and the later wisdom books are a sign of God's concern for mankind. There are actions that lead to blessings and life, but there are also those that lead to a curse and death. The man who is aware of this cause and effect reality decides about his behavior (Dt 30:15-20) and hands down this truth to his offspring. There are similarities between parenting and divine upbringing: "even as a man disciplines his son, so the LORD, your God, disciplines you" (Dt 8:5). The law of God is contained in the Decalogue (Ex 20:7-17; Dt 5), in the command to love God above all (Dt 5-11), in keeping His commandments, faithfully giving oneself to Him as Lord, and in showing brotherly love towards people (Dt 15:7; 17:15,20).

The obligation to love God "with all your heart, with all your soul, with all your strength" (Dt 6:5) is to remain in a father's heart, but it must also be inscribed in his sons in various life situations and times of the day: "recite them when you are at home and when you are away, when you lie down and when you get up" (Dt 6:7). These words are so important that they should be written and placed in one's hands, kept before their eyes, on doors and gates (Dt 6:89). Caring for justice, purity and holiness, the rejection of morally unacceptable acts, and getting rid of the evil that harms the whole community are recommended (Dt 21:21). Children should not be disobedient and defiant, but they must listen to the instructions of their father and mother (Dt 21:18).

Mattathias' example proves the importance of being faithful to the covenant with God, observing the cult of one's forefathers, keeping the Law and its precepts, opposing pagans, sinners and faithless people, and handing down the teachings to future generations. The non-adherence of other nations and the promise of honors did not change Mattathias' attitude, who remained faithful to the end and steadfast in his actions: "I and my sons and my kindred will keep to the covenant of our ancestors. Heaven forbid that we should forsake the law and the commandments. We will not obey the words of the king by departing from our religion in the slightest degree" (1 Mac 2: 20-22). Even though he was dying, he passed on to his children the contents he considered to be most valuable. He remembered the works of his ancestors, encouraged his children to be faithful to the covenant, motivated them to keep their proper attitudes even at the cost of their earthly lives, and pointed to the foundation of hope. 
"Therefore, my children, be zealous for the law and give your lives for the covenant of our ancestors. Remember the deeds that our ancestors did in their times, and you shall win great honor and an everlasting name" (1 Mac 2:50-51). This dying father tried to strengthen his children by reminding them of Abraham's faithfulness and justice, Joseph's keeping the commandments, the zealous Phineas, Joshua's obedience, Caleb's testimony, David's devotion, Elijah's concern for respecting the Law, the faithfulness of Hananiah, Azariah and Mishael, Daniel's innocence, and God's care for each of them. "And so, consider this from generation to generation, that none who hope in Heaven shall fail in strength" (1 Mac 2:61). The dying Mattathias cited salvation history, which he knew well, and instructed his children about a proper attitude towards God and a relationship with him who does not fail.

Closeness between God and man is also expressed in the relationship of being an educator. The psalmist writes: "Blessed is the man whom you instruct, O Lord, and teach him your Law" (Psalm 94:12). The psalms and the wisdom contained in the Book of Proverbs are types of prayers that educate people. In accord with this intentional goal, Solomon's proverbs, who was the King of Israel and son of David, were written "for gaining wisdom and instruction; for understanding words of insight; for receiving instruction in prudent behavior, doing what is right and just and fair" (Prov 1:2-3). An expression of parental concern for a son's proper conduct is addressed to him in the call: "My son, pay attention to my wisdom, turn your ear to my words of insight, that you may maintain discretion and your lips may preserve knowledge. Now then, my sons, listen to me; do not turn aside from what I say" (Prov 5:1-2,7).

The author of the Book of Wisdom writes about himself that "in swaddling clothes and with constant care I was nurtured" (Wis 7:4) and asks God for inspiration: "Now God grant I speak suitably and value these endowments at their worth: for he is the guide of Wisdom and the director of the wise" (Wis 7:15). The edited book presents numerous educational contents. It calls for justice and holiness that come from life-giving wisdom: "Love righteousness, you who judge the earth; think of the LORD in goodness, and seek him in integrity of heart" (Wis 1:1); "because into a soul that plots evil wisdom does not enter, nor does she dwell in a body under debt of sin" (Wis 1:4). The author explicitly points to doing what is right, encouraging the reader: "Do not court death by your erring way of life, nor draw to yourselves destruction by the works of your hands" (Wis 1:12). He draws 
attention to the fact that sin leads to death: "The souls of the righteous are in the hand of God, and no torment shall touch them" (Wis 3:1). He emphasizes that God's wisdom is a priceless treasure, leading a man in this earthly life and ensures immortality in eternity. "Wickedness does not prevail over Wisdom" (Wis 7:30).

The Book of the Wisdom of Sirach, pointing to the obligation to educate, warns us of over-indulgence that can cause confusion and straying from the right path. Parents are expected to be unambiguous in the attitudes and faithfulness to the laws they adopt. Education is a way to protect someone against evil. "Do you have sons? Correct them and cure their stubbornness in their early youth. Do you have daughters? Keep them chaste, and do not be indulgent to them" (Sir 7:23-24). Belittling evil by ignoring it through indifference or obscuring with smiles is not the proper strategy in the fight against what is unrighteous and sinful. When raising children, it is necessary to set expectations: "Discipline your son and make heavy his yoke, lest you be offended by his shamelessness. Do not give him his own way in his youth" (Sir 30:13,11). This does not mean, however, harshness without mercy.

The role-model for disciplining is God: "the Lord's compassion reaches all humanity, reproving, admonishing, teaching, and turning them back, as a shepherd his flock" (Sir 18:13b). The following words present the value of a good upbringing: "whoever disciplines a son will benefit from him, and boast of him among acquaintances" (Sir 30:2). Thanks to the message passed on to generations and its educational influence, the contents conveyed to the minds and hearts of descendants constitute a kind of extension of the life of their parents. "At the father's death, he will seem not dead, for he leaves after him one like himself" (Sir 30:4). Transmitting wisdom is also of great importance for the life of the students. "Happy those who meditate upon these things; wise those who take them to heart! If they put them into practice, they can cope with anything, for the fear of the LORD is their lamp" (Sir 50:28-29).

The Old Testament presents examples of well-disciplined people, including those who fulfilled the parental task of raising children. Susanna, the daughter of Hilkiah described in the Book of Daniel is such a person. "Her parents were righteous and raised their daughter according to the Law of Moses" (Dan 13:3). Blackmailed by hypocritical and perverse elderly men who planned to force her into sexual intercourse, Susanna managed to reply and her answer proved the righteousness of her heart, which she did not defile even in the face of a dangerous threat. "I am completely trapped,' Su- 
sanna groaned. 'If I yield, it will be my death; if I refuse, I cannot escape your power. Yet it is better for me not to do it and to fall into your power than to sin before the Lord'" (Dan 13:22-23). Faithful to the law above all and the readiness to accept undeserved suffering, so as not to break the principles learned, this testified to the effectiveness of the upbringing she received. This attitude is confirmed by the words: "nothing is worth more than her self-discipline" (Sir 26:14b).

Such a heroic attitude towards faithfulness to the law, which even the sight of torture and a martyr's death was not able to change, was present in the Jewish martyrs from the time of the Maccabean uprising (in the years 167-160 BC). The unbreakable mother and her seven sons, at the order of the ruler of Syria, Antiochus IV Epiphanes, were cruelly murdered for being faithful to their religious laws (2 Mac 7), which testifies to their deeply held religious upbringing. The mother, despite the cruel tortures that her sons were subjected to, remained faithful to God. Despite the proposal to spare his life in exchange for violating religious law, this mother did not urge her last and youngest son to do so. On the contrary, she strengthened him in the rightness of keeping his religious attitude, encouraged him with support at his upcoming death which would lead to life. "Do not be afraid of this executioner, but be worthy of your brothers and accept death, so that in the time of mercy I may receive you again with your brothers" (2 Mac 7:29).

Eleazar also refused to accept Pagan customs among the followers of Judaism (2 Mac 6:18-31). He was not persuaded to break religious rules or even pretended to do so. Beaten by a cruel scourging, he became an example of how to "prefer a glorious death to a life of defilement" (2 Mac 6:19). This 90-year-old man did not want to create a scandal, but gave a good example for the younger generation. "He made up his mind in a noble manner, worthy of his years, the dignity of his advanced age, the merited distinction of his gray hair, and of the admirable life he had lived from childhood, above all loyal to the holy laws given by God" ( 2 Mac 6:23). The mention of his perfect behavior since childhood may also be a testimony of the proper formation that he had received.

The author, when describing the events from the Maccabean times, added a note for the reader: "Now I urge those who read this book not to be disheartened by these misfortunes, but to consider that these punishments were meant not for the ruin but for the correction of our nation" (2 Mac 6:12). Serving to educate, the examples of good behavior worth following are also presented in the history of Shadrach, Meshach and Abednego, who were 
followers of the true God and did not agree to worship the golden statue. They were sentenced to death by burning but were miraculously saved.

This was recognized by Nebuchadnezzar as proof of the greatness of their God and the correctness of the faith they proclaimed (Dn 3). The history of Daniel cast into the cave of lions for praying to God is also educational (Dn 6:11-26). His being spared from death contributed to issuing the decree in which King Darius announced the acceptance of God as professed by Daniel: "For he is the living God, enduring forever, whose kingdom shall not be destroyed, whose dominion shall be without end, a savior and deliverer, working signs and wonders in heaven and on earth" (Dn 6:27-28a).

People who are improperly brought up cannot face heroic challenges or even follow the normal rules of savoir vivre. ${ }^{7}$ People without an education do not control their language, but instead invent stories at an inappropriate time (Sir 20:19). They cannot stand outside but peek inside through the door and eavesdrop. They cannot properly behave at the table. ${ }^{8}$ Upbringing obliges us to avoid revolting nosiness, greed, and reaching into a dish for whatever someone else has a desire to eat, grabbing for food first, or being insatiable and continuing to eat when others have finished (cf. Sir 31:12-19). Improper behavior among non-educated people is present everywhere, it is something typical of them, a bad habit, and an example are their lying words. "A lie is a foul blot in a person, yet it is always on the lips of the ignorant" (Sir 20:24).

Lack of proper upbringing causes negative effects. Sinful children, who were not taught God's commandments, are the reason for abandoning a widow and mother: "Let no one gloat over me, a widow, bereft of many; for the sins of my children I am left desolate, because they turned from the law of God, and did not acknowledge his statutes. In the ways of God's commandments they did not walk, nor did they tread the disciplined paths of his justice" (Ba 4:12-13). Likewise, it is a shame for a father to have a badly brought up son, and a badly raised daughter, as the Wisdom of Sirach claims, will bring shame upon her father (cf. Sir 22:3). Someone who does not suffer from remorse, despises their education, does not pay attention to the voice of educators or teachers and so can fall into great misfortune (Prov $5: 12-14)$.

\footnotetext{
${ }^{7}$ Stanisław KRAJSKI, Savoir vivre jako sztuka życia. Filozofia savoir vivre'u (Warszawa: Agencja SGK Ewa Jadwiga Krajska, 2007).

${ }^{8}$ Stanisław KRAJSKI, http://www.savoir-vivre.com.pl/?zachowanie-przy-stole-\%E2\%80\%93-wciaz -w-pelni-aktualny-material-z-miedzywojnia,797 (8.01.2018).
} 
Caring for children's right conduct and giving them the heritage of past generations is a special obligation and responsibility for parents. It is a responsibility we owe to ourselves, our children, society, and above all to God. The Book of Deuteronomy teaches us that we should obey, fear, and love our true God with all our heart, soul and strength (cf. Deut 6:5). The author of the book writes: "This then is the commandment, the statutes and the ordinances, which the LORD, your God, has commanded that you be taught to observe in the land you are about to cross into to possess" (Dt 6:1). We are to listen to His words and obey them, pass them on to our children in various ways, repeat and memorize them, accept and unite them to our lives (cf. Dt 6:2-4). The testimony of faith heard from our fathers cannot be hidden from our children. We must tell them about God and His works, teaching them to put their hope in Him and follow His instructions.

What we have heard and know; things our ancestors have recounted to us.

We do not keep them from our children; we recount them to the next generation, The praiseworthy deeds of the LORD and his strength, the wonders that he performed.

God made a decree in Jacob, established a law in Israel:

Which he commanded our ancestors, they were to teach their children;

That the next generation might come to know, children yet to be born.

In turn they were to recount them to their children, that they too might put their confidence in God, and not forget God's deeds, but keep his commandments (Ps 78:3-7).

The role of parents, just like pastors of sheep, is to lead their children prudently, teaching them righteousness of heart (Ps 78:72).

\section{EDUCATIONAL INSTRUCTIONS IN THE NEW TESTAMENT}

Already in the Old Testament's Song of Songs we can read about love as God's fire (Song 8:6). The value of love cannot be defeated: "Great waters cannot quench love" (Song 8:7a). It is also incomparable to anything else: "Were one to offer all the wealth of his house for love, he would be utterly despised" (Song 8:7b). In the New Testament, Love is revealed in its fullness in the Person of Jesus Christ: "For God so loved the world that he gave his only Son, so that everyone who believes in him might not perish but might have eternal life" (J 3:16). Through His earthly life, the God-Man teaches people how to live. An expression of faith in God and loving him is to keep his commandments ( $\mathrm{J}$ 14:15,21). The greatest of these is the commandment to love, which Jesus himself states: "The first is this: 'Hear, O Israel! 
The Lord our God is Lord alone! You shall love the Lord your God with all your heart, with all your soul, with all your mind, and with all your strength.' The second is this: 'You shall love your neighbor as yourself.' There is no other commandment greater than these" (Mk 12:29-31).

Jesus said to his disciples: "I give you a new commandment, that you love one another, just as I have loved you" (J 13:34), and after the washing of the disciple's feet, he added: "I have given you an example to follow, so that as I have done for you, you should also do" (J 13:15). St. Paul reminds us: "Owe nothing to anyone, except to love one another; for the one who loves another has fulfilled the law. The commandments, 'You shall not commit adultery; you shall not kill; you shall not steal; you shall not covet,' and whatever other commandments there may be, are summed up in this saying, namely 'You shall love your neighbor as yourself.' Love does no evil to the neighbor; hence, love is the fulfillment of the law" (Rom 13:810). The commandment of love is the main foundation and goal of education. ${ }^{9}$ This is the most important issue that parents should pass on to their children. They are also supposed to help in its implementation so that it becomes the core of their lives. "The message of faith," stated Holy Father Pope Francis, "can only be accomplished 'in a dialect,' meaning the family dialect of mothers and dads, grandmothers and grandfathers, in the dialect of the love of your family home." 10

The task of believers is to listen to the Law contained in the Sacred Scriptures, but also to be obedient and follow it (Rom 2:12). At the same time, we need to be sensitive to the voice of our conscience, which is the guardian of right behavior (Rom 2:15). Parents are educators of their own children, and it is necessary that they conform their actions with what they preach. Formation is not simply about verbal teachings but above all about one's example present through their deeds. ${ }^{11}$ This is in line with contemporary psychology and developmental pedagogy, because a child's primary way of adopting specific contents is to observe someone's behavior and actions. ${ }^{12}$ An example of ineffective education would be the command "do not

\footnotetext{
${ }^{9}$ Urszula Dudziak, "Powołanie do miłości." Pielgrzym [Czasopismo Polonii katolickiej w Kanadzie], no 15 (October 1989): 1, 24.

${ }^{10}$ http://pl.radiovaticana.va/news/2018/01/07/papie\%C5\%BC_wiar\%C4\%99_trzeba_przekazywa \%C4\%87_w_dialekcie_mi\%C5\%82o\%C5\%9Bci/1357873 (date online: January 7, 2018).

${ }^{11}$ Piotr MAZur, Podstawy pedagogiki pastoralnej (Kraków: Wyższa Szkoła Filozoficzno-Pedagogiczna “Ignatianum," Wydawnictwo Apostolstwa Modlitwy, 2011), 110-114, 153-162.

${ }^{12}$ Wojciech Kulesza, Efekt Kameleona. Psychologia naśladownictwa (Warszawa: Wydawnictwo Naukowe Scholar, 2016); Marco Iacoboni, Mirroring People. The New Science of How
} 
steal" given by a person who steals, and a similar matter is an adulterer who says that adultery is not allowed. A false attitude is to praise the Law while at the same time dishonoring God by transgressing the Law. Such incongruent attitudes become an anti-testimony.

This is also the reason why people depart from God. They see such behavior, are shocked and then blaspheme against God who has such false followers. St. Paul in the Letter to the Romans warns against behavior that does not educate but only deprives others (see Rom 2:17-24). Those who teach others are also required to teach themselves. Self-discipline and selfformation are indispensable for parents' educational commitment. It proves their real concern for their children and, thanks to their being authentic, also makes their educational efforts more effective. Parents should be more concerned about their children than any educator. Being a father definitely means much more than being an educator. A father's task is not only to raise children, but directly give birth to his children for Christ. This obliges parents to hand down teachings, but also to become a model worth following (see 1 Cor 4:15-16).

Good upbringing is not just about sticking to the letter of the Law resulting from fear of an external authority figure. Instead of remaining at the level of legalism, it is advisable to introduce the child to perfect motivations for righteousness that flow from the heart. Faithfulness, love and unity with Jesus direct one's actions to be even nobler than an orthodox practice of doing one's obligations. In the beginning, it was the Law itself that was the educator that was supposed to lead people to God. When one is baptized, we are clothed in Christ and, being one with Him, became sons of God ( Gal 3:23-29). All people, however, just like the Galatians who were called to freedom, are also given a warning: "For you were called for freedom, brothers. But do not use this freedom as an opportunity for the flesh; rather, serve one another through love" (Gal 5:13).

The entire law is summarized in the commandment to love (Gal 5:14; Rom 13:8-9). What should be passed on to children in the process of educating them is the following instruction: "Love does no evil to the neighbor; hence, love is the fulfillment of the law. ... Let us then throw off the works of darkness and put on the armor of light; let us conduct ourselves properly

We Connect with Others (New York: Farrar, Straus and Giroux, 2009); Psychologia rozwoju człowieka, ed. Barbara Harwas-Napierała, Janusz Trempała (Warszawa: Wydawnictwo Naukowe PWN, 2000); Stanisław KUlPACZYŃSKI, Psychologia rozwojowo-wychowawcza nie tylko dla katechetów (Lublin: Polihymnia, 2009). 
as in the day" (Rom 13:10;12b-13a). A Christian, an alter Christus, ought to shine like a person clothed in the Lord's light. God's love became incarnate in the Person of Jesus, and Christ's followers ought to shine brightly with this love.

The Scriptures explicitly teach us what the relationship between parents and children should be like. The fourth commandment of the Decalogue shows that children owe their parents obedience and honor (Ex 20:12; Dt 5:16). The Letter to the Ephesians clarifies that obedience in the Lord is right behavior (Eph 6:1). Warnings addressed to fathers include that they not provoke their children to anger. It is advisable, however, to apply discipline and exhortations in education (Eph 6:4). Just like the Old Testament, the New Testament also orders us to be the witness of "what was from the beginning, what we have heard, what we have seen with our eyes, what we looked upon and touched with our hands concerns the Word of life, for the life was made visible" (1 J 1:1-2a). The coming of Christ is connected with the renewal of life. It is a commitment to reject everything that is unworthy of being a child of God: debauchery, impurity, evil desires, greed, idolatry, anger, impetuosity, jealousy, insult, disgraceful speech, and lies (Col 3:5). Parents should remember these and remind children of the advice given to the Colossians:

Put on then, as God's chosen ones, holy and beloved, heartfelt compassion, kindness, humility, gentleness, and patience, bearing with one another and forgiving one another, if one has a grievance against another; as the Lord has forgiven you, so must you also do. And over all these put on love, that is, the bond of perfection. And let the peace of Christ control your hearts, the peace into which you were also called in one body. And be thankful. Let the word of Christ dwell in you richly, as in all wisdom you teach and admonish one another, singing psalms, hymns, and spiritual songs with gratitude in your hearts to God. And whatever you do, in word or in deed, do everything in the name of the Lord Jesus, giving thanks to God the Father through him (Col 3:12-17).

Constantly keeping Sacred Scriptures in mind has a great value. It allows us to draw from healthy teachings, to be in close contact with God and experience heartfelt transformation. "Indeed, the word of God is living and effective, ... and able to discern reflections and thoughts of the heart" (Heb 4:12).

As a consecrated God, saints and beloved ones, put in loving mercy, goodness, humility, meekness, patience, endure one another and forgive To each other, if someone has an accusation against another: how the Lord has forgiven you, yes you! On top of this, put everything [put on] love that is a symbol of perfection. 
Let Christ's peace be commanded by your hearts, to whom you have been called in one body. And you are grateful! Let the word of Christ abide in you with all your richness: pray with all wisdom and exhort yourself with psalms, hymns, fiends full of spirit, under the influence of grace, singing to God in your hearts. And whatever you do with word or deed, do everything in the name of the Lord Jesus, thanking God for His Father (Col 3:12).

Permanent contact with Scripture is valuable. It allows us to accept healthy learning, stay close to God, and experience a change of heart. "Indeed, the word of God is living and effective, ... and able to discern reflections and thoughts of the heart" (Heb 4:12).

Upbringing and parental care deserve gratitude. Children and grandchildren are supposed to be instructed as follows: "let these first learn to perform their religious duty to their own family and to make recompense to their parents" (1 Tm 5:4b). Care and reverence should be extended to the widow who, among her list of merits, has done the following: "she has raised children, practiced hospitality, washed the feet of the holy ones, helped those in distress, and involved herself in every good work" (1 Tm 5:9-10).

Psychological and pedagogical analyses of the multiple aspects of education show that committed parenthood brings double positive results. On the one hand, parenthood creates the proper conditions for the development of children, and on the other hand, it also brings benefits to parents in their self-creation. ${ }^{13}$ Contemporary researchers, in a sense, are rediscovering and confirming the Franciscan principle: "in giving, we receive." ${ }^{14}$ Returning to the sources that help to improve parenting skills promotes self-development.

Guidebooks by Christian advisors can help us in practically applying these biblical guidelines on how parents can have an educational influence on their children. Particularly noteworthy are books by Mariola and Piotr Wołochowicz, who teach us how to raise religious children and how to help those who have departed from practicing the faith. ${ }^{15}$ Josh McDowell's book

\footnotetext{
${ }^{13}$ Lucyna BAKIERA, Zaangażowane rodzicielstwo a autokreacyjny aspekt rozwoju dorostych (Warszawa: Difin, 2013).

${ }^{14}$ Św. FrancisZeK Z AsYżu, Modlitwa o pokój, http://www.franciszkanie.net/artykul/202, modlitwa_o_pokoj/ (11.01.2018).

${ }^{15}$ Mariola i Piotr WoŁochowiczowie, Wierzace dzieci. O tym jak wychowywać dzieci do dojrzatej wiary (Kraków: Wydawnictwo Światło-Życie, 2014); Mariola i Piotr WoŁochowiczowIE, Wierzace dzieci. Reanimacja. O tym jak odbudować w dzieciach żywa wiarę (Kraków: Wydawnictwo Światło-Życie, 2015); Piotr WoŁochowicz, Wierzace dzieci. Ugruntowanie i rozwój. O tym, jak tworzyć dobre środowisko przekazu wiary (Kraków: Wydawnictwo Światło-Życie, 2018).
} 
The Myths of Sexual Education, ${ }^{16}$ a valuable guide for parents and teachers, should be found in every home and school library. It deals with "making straight the paths" of sexual education. Other valuable publications also include those that prove the superiority of parental education over putting children in nursery and pre-school institutions and leaving them under the supervision of strangers. ${ }^{17}$ The presence of parents, their closeness, love, sharing the experience and testimony of faith, those who cooperate and care to create and direct the received gift of life cannot be replaced by anyone else.

\section{THEOLOGICAL SOURCES}

Pismo Święte Starego i Nowego Testamentu w przekładzie z języków oryginalnych. Opr. zespół biblistów polskich z inicjatywy benedyktynów tynieckich [The Holy Scriptures of the Old and New Testaments translated from original languages. Translated by Poland's Biblical scholars at the initiative of the Benedictines of Tyniec]. Poznań-Warszawa: Pallotinum, 1980.

Obrzędy Chrztu dzieci dostosowane do zwyczajów diecezji polskich [Baptism Rites for Children adapted to the Customs of Poland's Dioceses]. Katowice: Księgarnia Św. Jacka, 2005.

Obrzędy Sakramentu Matżeństwa dostosowane do zwyczajów diecezji polskich [Rites of the Sacrament of Marriage adapted to the customs of Poland's Dioceses]. Katowice: Księgarnia Św. Jacka, 2007.

United States Conference of CATHolic Bishops. The Books of the Bible. http://usccb.org/bible (28.03.2019).

\section{LITERATURE}

Bagrowicz, Jerzy, Stanisław Jankowski. „Pan Bóg twój, wychowuje ciebie” (Pwt 8,5). Studia z pedagogii biblijnej ["The Lord your God Brings You Up" (Dt 8:5). Studies in Biblical Pedagogy]. Torun': Wydawnictwo UMK, 2005.

BORKOwSKI, Tomasz. "Wartości religijne. Kształtowanie postaw religijnych człowieka" [Religious Values. Shaping the Religious Attitudes of Man]. Fides et Ratio 1(17) (2014): 166-178.

ChaŁAs, Krystyna. Wychowanie ku wartościom. Elementy teorii i praktyki [A Values Education. Elements of Theory and Practice]. Lublin-Kielce: Jedność, 2006.

Dudziak, Urszula. "Powołanie do miłości." Pielgrzym [Czasopismo Polonii katolickiej w Kanadzie] [A Call to Love, "Pilgrim" [Journal of the Catholic Polonia in Canada]], no 15 (October 1989): 1, 24.

\footnotetext{
${ }^{16}$ The Myths of Sex Education: Josh McDowell's Open Letter to his School Board. Nashville, Tenn.: Thomas Nelson, 1993.

${ }^{17}$ Jill Savage, Mama-najlepszy zawód na świecie, trans. Małgorzata Szymańska, Agnieszka Marianowicz-Szczygieł (Warszawa: Vocatio, 2007); Mariola i Piotr WoŁochowiczowIE, "Czy chrześcijańskie dziecko powinno chodzić do przedszkola," TIPS—Pomysty dla chrześcijańskich rodzin no 16: 1-4, [addition to Absolutnie Fantastyczne 1998, no. 1]; Mariola i Piotr WoŁoCHOwICZ, "Nie składajmy dzieci na ofiarę," Cel no 1(94) (2006), 20-21, 32.
} 
DZIEWIECKI, Marek. Wychowanie duchowe, moralne i religijne chłopców. Od urwisa do bohatera [Spiritual, Moral and Religious Education for Boys. From a Scamp to a Hero]. (Kraków: Wydawnictwo eSPe, 2013).

FLIS, Jan. Konkordancja Starego i Nowego Testamentu do Biblii Tysiaclecia [The Thousand Years Bible Concordance of the Old and New Testaments]. Warszawa: Fundacja Misyjna Świeckich, 1991.

FRANCISZEK, papież: Wiarę trzeba przekazywać w dialekcie mitości [Belief Must Be Conveyed in the Dialect of Love],

http://pl.radiovaticana.va/news/2018/01/07/papie\%C5\%BC_wiar\%C4\%99_trzeba_przekazywa\%4\% 87_w_dialekcie_mi\%C5\%82o\%C5\%9Bci/1357873 (7.01.2018).

IAcoboni, Marco. Mirroring People. The New Science of How We Connect with Others. New York: Farrar, Straus and Giroux, 2009.

KrAJSKI, Stanisław. http://www.savoir-vivre.com.pl/?zachowanie-przy-stole-\%E2\%80\%93-wciazw-pelni-aktualny-material-z-miedzywojnia,797 (8.01.2018).

KRAJSKI, Stanisław. Savoir vivre jako sztuka życia. Filozofia savoir vivre'u [Savoir vivre as the Art of Life. The Philosophy of savoir vivre]. Warszawa: Agencja SGK Ewa Jadwiga Krajska, 2007.

KulESZA, Wojciech. Efekt Kameleona. Psychologia naśladownictwa [The Chameleon Effect. Psychology of Immitation]. Warszawa: Wydawnictwo Naukowe Scholar, 2016.

KUlPACZYŃSKI, Stanisław. Psychologia rozwojowo-wychowawcza nie tylko dla katechetów [Developmental and Educational Psychology not Only for Catechists]. Lublin: Polihymnia, 2009.

Kunowski, Stefan. Podstawy wspótczesnej pedagogiki [Fundamentals of Contemporary Pedagogy]. Warszawa: Wydawnictwo Salezjańskie, 2004.

Mazur, Piotr. Podstawy pedagogiki pastoralnej [Fundamentals of Pastoral Pedagogy]. Kraków: Wyższa Szkoła Filozoficzno-Pedagogiczna "Ignatianum," Wydawnictwo Apostolstwa Modlitwy, 2011.

McDowell, Josh. Mity edukacji seksualnej [Sex Education Myths]. Warszawa: Vocatio, 2000.

NowaK, Marian. Teorie i koncepcje wychowania [Theories and Concepts of Education]. Warszawa: Wydawnictwo Akademickie i Profesjonalne, 2008.

Przetacznik-Gierowska, Maria, Ziemowit WŁodarski. Psychologia wychowawcza [Psychology of Raising Children]. Warszawa: Wydawnictwo Naukowe PWN, 2017.

Psychologia rozwoju czlowieka [Psychology of Human Development], edited by Barbara Harwas-Napierała, Janusz Trempała. Warszawa: Wydawnictwo Naukowe PWN, 2000.

Religijno-moralny wymiar rozwoju i wychowania [Religious and Moral Dimensions of Development and Upbringing], edited by Alina Rynio, Katarzyna Braun, Anna Lendzion i Danuta Opozda. Lublin: Wydawnictwo KUL, 2012.

Savage, Jill. Mama-najlepszy zawód na świecie [Mother. The Best Profession in the World]. Translated by Małgorzata Szymańska, Agnieszka Marianowicz-Szczygieł. Warszawa: Vocatio, 2007.

SiERoŃ, Roman B. Model wychowania chrześcijańskiego wedtug św. Pawła Apostoła [The Christian Education Model According to St. Paul the Apostle]. Ružomberok-Stalowa Wola: Wydawnictwo Diecezjalne i Drukarnia w Sandomierzu, Katedra Pedagogiki Katolickiej KUL, 2008.

Sztuka kierownictwa duchowego [The Art of Spiritual Direction], edited by Józef Augustyn, Jakub Kołacz. Kraków: Wydawnictwo Apostolstwa Modlitwy, 2007. 
ŚLIWERSKI, Bogusław. Wspótczesne teorie i nurty wychowania [Contemporary Theories and Currents of Education]. Kraków: Impuls, 2001.

WALESA, Czesław. "Psychologiczna analiza rozwoju religijności człowieka ze szczególnym uwzględnieniem pierwszych okresów jego ontogenezy" [Psychological Analysis of the Development of Man's Religiousness, with Particular Reference to the First Periods of his Ontogenesis]. In Psychologia religii, edited by Zdzisław Chlewiński, 143-180. Lublin: TN KUL, 1982.

WoŁochowicz, Mariola i Piotr. "Czy chrześcijańskie dziecko powinno chodzić do przedszkola." TIPS - Pomysty dla chrześcijańskich rodzin [Should a Christian Child Go to Pre-School, "TIPS and Ideas for Christian Families], no 16: 1-4, [addition to Absolutnie Fantastyczne no 1 (1998)]

WoŁochowicz, Mariola i Piotr. "Nie składajmy dzieci na ofiarę" [Let's not Sacrifice our Children]. Cel no 1 (94) (2006): 20-21, 32.

WoŁochowicz, Piotr. Wierzace dzieci. Ugruntowanie i rozwój. O tym, jak tworzyć dobre środowisko przekazu wiary [Believing Children. Foundations and Development. How to Create a Good Environment for Teaching the Faith]. Kraków: Wydawnictwo Światło-Życie, 2018.

WoŁochowiczowie, Mariola i Piotr. Wierzace dzieci. O tym jak wychowywać dzieci do dojrzatej wiary [Believing Children. On How to Raise Children to a Mature Faith]. Kraków: Wydawnictwo Światło-Życie, 2014.

WoŁochowiczowie, Mariola i Piotr. Wierzace dzieci. Reanimacja. O tym jak odbudować w dzieciach żywa wiare [Believing Children. Resuscitation. How to Create a Living Faith in Children]. Kraków: Wydawnictwo Światło-Życie, 2015.

Translated by Jan Kobytecki

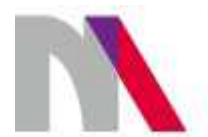

The preparation of the English version of Roczniki Teologiczne (Annals of Theology) and its publication in electronic databases was financed under contract no. 836/P-DUN/2018 from the resources of the Minister of Science and Higher Education for the popularization of science. 